\title{
THE INFLUENCE OF MIXING SOLID PARTICLES ON THE KINETIC OF BENZOIC ACID DISSOCIATION DURING THE PNEUMATIC MIXING OF SOLUTION
}

\begin{abstract}
The current research characterizes the regularities of the process of polydisperse mixture of benzoic acid dissociation during the pneumatic mixing of solution. The advantages of using compressed air for dissolution are presented. The authors also describe the method of conducting experimental investigations. The research is focused on the using of solid and chemically inert mixing additives, which supply into the process at the beginning. The authors have estimated the influence of these solid particles of different forms, which were produced by chemically inert to benzoic acid materials (glass, plastic, rubber, polyacetal), and in the process pneumatic mixing, and, correspondingly, on the kinetic of benzoic acid dissolution in water. We have also discovered that optimal for mixing of benzoic acid solution particles have spherical shape, which are made of plastic, and have diameter $7 \mathrm{~mm}$ and specific density $1280 \mathrm{~kg} / \mathrm{m}^{3}$. Experimental investigations enabled the determination of the fact that introduction of mixing additives in the quantity of $2 \%$ from the volume of solution is critical and sufficient for avoiding of passing out of the solid phase in the foam layer and reduce the dissolution time to the necessary concentration. We have also investigated the influence of mixing additives on the dissolution duration and energy expenses. The maximum permissible compressed air flow rate for prevention of solution transition into foam state was determined. Furthermore, the impact of compressed air flow rate variation on the kinetic of dissolution process was investigated. The analysis of graphic dependency reveals that adding of mixing additives and increasing of compressed air consumption reduces the average duration of dissolution process. From the other side, such consumption of compressed air is critical in conditions of current research, as its further increasing over $5.6 \mathrm{~m}^{3} /$ hour leads to transformation of $80 \%$ of solution into foam. Finally the kinetic of benzoic acid dissolution to the concentration $1.2 \mathrm{~kg} / \mathrm{m}^{3}$ with using of mixing additives in the conditions of incomplete solution saturation was experimentally determined and analysed.
\end{abstract}

Keywords: dissolution; mixing; bubbler; foam creation; mass exchange; kinetics.

Introduction. Dissolution of solid disperse materials applies in technological processes of chemical, food, pharmaceutical, and other industrial branches. Dissolution is complicated and energy consuming mass exchange process of interphase interaction of substances in the solid - liquid phase system. The effectivity and intensity of the process influences the cost of the final product. There exists a variety of methods for intensification of poly disperse solid materials dissolution, namely: mechanical and pneumatic mixing; dissolution in the liquid flux when its velocity constantly changes or pulsing; by hydrodynamic cavitation; by overlaying of energy fields; vibration; and other methods. During the analysis of existing methods of continuous dissolution of solid substances, the pneumatic mixing can be considered as one of the perspective methods, which do not require complicated accessories and can be easily automated. The major benefit of using of compressed air is uniform and intensive mass exchange between solid phase and liquid. The use of bubbled air ensures also the constant solution temperature; the heat, which emits during the transformation of solid phase into liquid, transmits outside the apparatus together with bubbles (Danyliuk et al., 2017), and this establish the process stationarity. Disadvantages of pneumatic mixing are possible oxidation of solid material particles by air, which enters the apparatus; and foam creation, which negatively impacts the mass exchange between solid and liquid phases (Danyliuk \& Atamaniuk, 2017). For avoiding of foam formation, in the industry there uses chemical means, namely the surfactants, which reduces the viscosity of solution and prevents creation of foam. The solution of the problem in such manner is not completely suitable in the investigated case, because such substances pollutes the final product, and also make technological process more complicated, which negatively impacts the overall economical parameters of the project. There exist other methods of elimination of foam creation also, namely: ultrasonic, using of nosepieces for foam destruction, and other. However, all mentioned methods involve additional energy expenses and material resources, and complication of dissolution apparatus construction.

\section{Інформація про авторів:}

Данилюк Олег Михайлович, аспірант, кафедра хімічної інженерії. Email: mr.danuk.91@gmail.com

Атаманюк Володимир Михайлович, д-р техн. наук, професор, завідувач кафедри хімічної інженерії. Email: atamanyuk@ukr.net; https://orcid.org/0000-0002-8707-2319

Гнатів Зоряна Ярославівна, канд. техн. наук, асистент, кафедра хімічної інженерії. Email: zorchyk@gmail.com

Цитування за ДСТУ: Данилюк О. М., Атаманюк В. М., Гнатів 3. Я. The influence of mixing solid particles on the kinetic of benzoic acid dissociation during the pneumatic mixing of solution. Науковий вісник НЛТУ України. 2018, т. 28, № 7. С. 92-96.

Citation APA: Danyliuk, O. M., Atamaniuk, V. M., \& Hnativ, Z. Ya. (2018). The influence of mixing solid particles on the kinetic of benzoic acid dissociation during the pneumatic mixing of solution. Scientific Bulletin of UNFU, 28(7), 92-96.

https://doi.org/10.15421/40280720 
Literature review. Problems of foam creation and its destruction are actual, and generalizations of experimental data and theoretical investigations in modern monographies reveals the problem (Garrett, 2014; Kotelnykova \& Alikov, 2011; Exerowa \& Kruglyakov, 1998). In the mentioned researches there were investigated kinetic regularities of foam destruction by silicon oils and foam destructors of ethanol type in water solutions of polyacrylamide and sodium lauryl sulfate as anionic surfactant. Foam creation during the production of the nitrogen fertilizers with additions (for example, production of hydrogumatic) is often the reason for accidents, reduces the quality of product, and total manufacturing productivity (Kraievskyi \& Mykhailova, 2009). In some food production branches, the problem of foam creation also require solution. One of the examples can be considered sugar production. Due to the microorganisms living activities (which consumes saccharides during metabolism), there creates foam as a result of emitted metabolic gases. Technological stations of sugar production, where observes the creation of foam, require equipping with dozing devices and equipment for preparation of water emulsions with addition of surfactants, or by using of centrifuges (Anisimova, 2014). Authors of the research (Shtanheieva et al., 2000) investigated the dependency foam creation ability of transportation and washing water from the concentration of foam creators, such as saponin, pectin substances, colloid-disperse substances during the technological process of sugar production. The reduction of foam creation in the transportation and washing water can be reached by the implementation of pressure flotation in such water purification systems, which allow performing of additional water purification with further its using for washing of beetroots. In the research (Yureva, 2003) there was investigated the ability of vegetable oils to prevent the milk foam firmness. There was proved the expedience of using of emulsified palm oil for milk foam destruction. There was investigated the influence of liquid nitrogen, UHF and microwave influence on the milk foam stability, and determined the change of milk content after electro physical treatment.

Authors (James, 2007) determined the feasibility of foam destruction by the ultrasonic waves of different frequencies. In the research (Fazilet, 1998) there represented results of investigations of foam creation in biological processes, mechanism of foam creation and destruction, and also methods of its control. Specific attention is paid to chemical methods of struggle with foam creation and these methods efficiency. Additionally, there justifies the selection of foam destructors. In the research (Karakashev \& Grozdanova, 2012) there was investigated the research methods, and the conditions of creation and destruction of foam. Specifically, there was investigated the interferometry method of determination of thickness of thin liquid films for systematic investigation of bubbles behavior. In the research (Fink, 2015) there describes application of foam creators and foam destructors during the oil and gas extraction processes during drilling and cementation of wells. The author (Garrett, 2015) investigated the influence of foam destructors and methods of mechanical destruction of foam and destruction of foam by ultrasonic. Additionally there was investigated the destruction of foam due to microgravity. The feasibility of foam destruction intensification by mechanical device with perforated plates, which facilitates foam fractioning, was investigated in the research (Liu et al., 2013). As a rule, processes of dissolution are investigated in two directions: research of the solubility and process kinetics, intensification methods; and struggle against foam creation.

Authors in the research (Shapoval et al., 2017), based on dependences of velocity constant for initial sections of foam destruction from foam destruction concentrations, performed the efficiency estimation and selection of foam destructors, considering the possibility of creation of emulsion in the system of water-based lubrication and cooling technological fluids for metal treatment. In the research (Karakashev \& Grozdanova, 2012) there was investigated the main stages and methods of research of foam creation and destruction, additionally there investigates the foam generation mechanism, namely there states that elasticity modulus of foam bubbles corresponds for the further lifetime of foam created.

The literature survey reveals prevailing of mechanical methods of foam destruction over chemical. That is why the investigation of energy efficient methods of mechanical foam destruction is actual for a number of manufactories of chemical, food, pharmaceutical, and other industries. The purpose of the investigation is research of the process of dissolution of polydisperse mixture of benzoic acid during the pneumatic mixing of solution and destruction of foam, which appears during the process. The main benefit of such method application is uniform and intensive mass exchange between solid phase and solvent in the whole volume of apparatus. Mixing by compressed air allow improving of the process without complicating the apparatus construction by mixing devices.

During the pneumatic mixing, the increasing of compressed air consumption allow intensifying the dissolution process, reduce its duration, and simultaneously increases the quantity of created foam. The research is focused on the using of solid and chemically inert mixing additives, which supplies into the process at the start. Thus, there improves mixing efficiency, and simultaneously reduces the quantity of created foam. Tasks of the research were: selection of quantity of mixing additives with their geometric and physical characteristics, which will insignificantly influence the energy consumption and, simultaneously, support mass exchange process intensification during dissolution; and also investigation of kinetic regularities of benzoic acid foam dissolution process.

The object of the investigation was the dissolution process of benzoic acid in water during pneumatic mixing, and influence of solid chemically inert mixing additives, entering the process in the initial phase, on the intensity and efficiency of dissolution and foam destruction. The process of interaction of benzoic acid with water is complicated, and, despite of the fact that its density is greater than the solvent density (distilled water), during the bubbling the majority of solid particles are situated outside of the mass exchange zone. They hangs up inside the foam and lays on the apparatus walls above the liquid level, thus do not participate in dissolution and in such manner increase the process duration, thus, the struggling against the foam creation is actual.

Experimental investigations. The investigation of benzoic acid dissolution was performed by the experimental stand according to the methodology, described in (Danyliuk et al., 2017). The content of dissolved acid $C_{m}$ was determined according to standard methodologies by spectral photometer Specord $\mathrm{m} 40$, and based on that data there was created the dependency graph of benzoic acid concentration in solution change in time $C=f(\tau)$. 
The solid chemical inert additive, which was entered into solution at the start of the process, there were used plastic spheres of diameter $7 \cdot 10^{-3} \mathrm{~m}$ and specific density $1280 \mathrm{~kg} / \mathrm{m}^{3}$, which were added in quantities $0.2-6.0 \%$ of total solution volume. Before the experiment initiation the solution bubbling was started, and there was mixed the portion of benzoic acid and inert mixing additives. The dissolution occurred during the time of 10 minutes, with sampling interval 2 minutes. The experimental results are represented in the Figure 1.

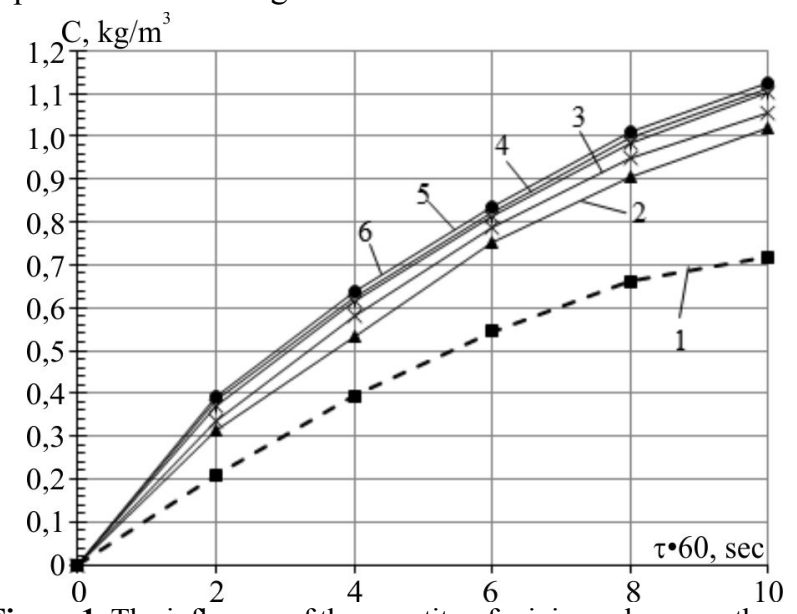

Figure 1. The influence of the quantity of mixing spheres on the dissolution process kinetics: 1) $M_{k}=0 \mathrm{~kg}$; 2) $M_{k}=12.9 \cdot 10^{-3} \mathrm{~kg}$; 3) $M_{k}=26.4 \cdot 10^{-3} \mathrm{~kg}$; ) $M_{k}=37.38 \cdot 10^{-3} \mathrm{~kg}$; 5) $M_{k}=70 \cdot 10^{-3} \mathrm{~kg}$; 6) $M_{k}=100 \cdot 10^{-3} \mathrm{~kg}$

During analysis of Figure 1, there can be concluded that adding of inert mixing additives intensifies the dissolution process, however, the growth their quantity over $2 \%$ $\left(M_{k}=37.38 \mathrm{~g}\right)$ from the total volume of solution do not lead to the significant growth of mixing intensity, and energy consumption during that increases. Considering the practical findings, it was concluded that the optimal quantity of mixing additives is $2 \%\left(M_{k}=37.38 \mathrm{~g}\right)$ from the total volume of solution. Such value prevents shifting of solid phase in the foam layer, intensifies the dissolution and reduces the duration of process, and, correspondingly, energy expenses.

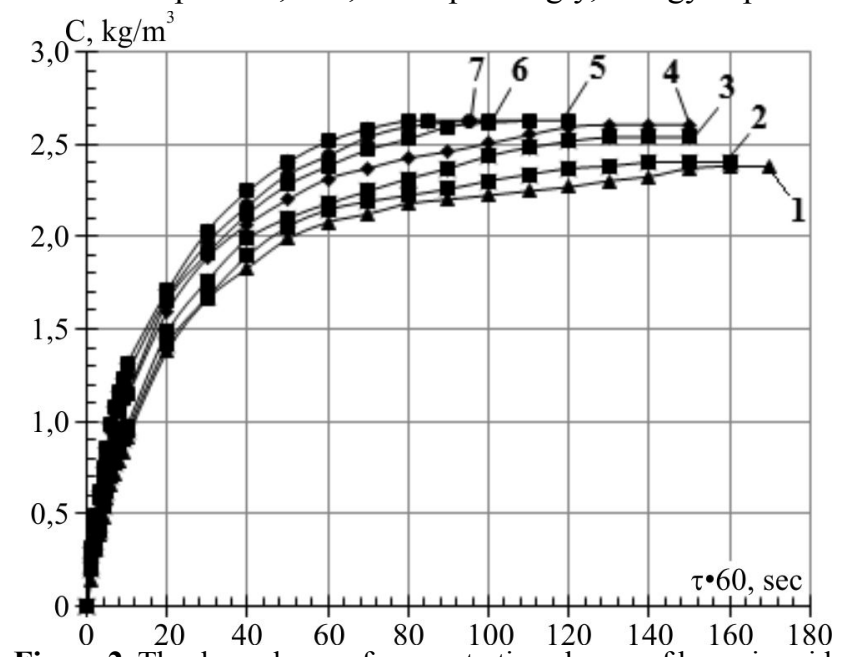

Figure 2. The dependency of concentration change of benzoic acid in time with the variation of compressed air consumption: 1) $V_{c}=22 \cdot 10^{-5} \mathrm{~m}^{3} / \mathrm{sec}$; 2) $V_{c}=44 \cdot 10^{-5} \mathrm{~m}^{3} / \mathrm{sec}$; 3) $V_{c}=67 \cdot 10^{-5} \mathrm{~m}^{3} / \mathrm{sec}$; 4) $V_{c}=89 \cdot 10^{-5} \mathrm{~m}^{3} / \mathrm{sec}$; 5) $V_{c}=111 \cdot 10^{-5} \mathrm{~m}^{3} / \mathrm{sec}$; 6) $V_{c}=133 \cdot 10^{-5} \mathrm{~m}^{3} / \mathrm{sec}$; 7) $V_{c}=156 \cdot 10^{-5} \mathrm{~m}^{3} / \mathrm{sec}$

The dissolution kinetics, when other parameters remain constant, additionally depends on the compressed air consumption, which is used for solution pneumatic mixing. Fi- gure 2 represents the kinetics of dissolution process of benzoic acid under various consumptions of pneumatic mixing to the saturation concentration, and using of mixing additives in the quantity $2 \%$ from the total volume of solution.

The analysis of graphic dependency (Figure 2) reveals that adding of mixing additives and increasing of compressed air consumption up to $5.6 \mathrm{~m}^{3} /$ hour reduces the average duration of dissolution process between $200 \mathrm{~min}$ (1) and $130 \mathrm{~min}$. From the other side, such consumption of compressed air is critical in conditions of current research, as its further increasing over $5.6 \mathrm{~m}^{3}$ /hour leads to transformation of $80 \%$ of solution into foam.

The allowable content of benzoic acid in food products is between 0.1 and $0.2 \%$. Usually, in food and pharmaceutical industries there uses solution of concentration $0.12 \%$. Additionally to benzoic acid dissolution process to saturation concentration $C_{s a t}$, the investigation of the kinetics of its solution to concentration $C=0.12 \%\left(1.2 \mathrm{~kg} / \mathrm{m}^{3}\right)$ is essential. During the dissolution, there also applied mentioned above mixing additives. The process was conducted at the steady temperature conditions $t=16{ }^{\circ} \mathrm{C}$, pressure $P=0.5$ atm., material mass $m=7 \cdot 10^{-3} \mathrm{~kg}$, and solution volume $V=1.5 \cdot 10^{-3} \mathrm{~m}^{3}$. The compressed air consumption changed in the range $V_{c}=0.8-5.6 \mathrm{~m}^{3} /$ hour.

Before reaching the desired concentration $C=0.12 \%$, there was performed periodic gathering of specimens $V=5 \cdot 10^{-6} \mathrm{~m}^{3}$ with time interval $\Delta \tau=60 \mathrm{sec}$. and analyzed the solution on the benzoic acid content. The kinetics of the dissolution process until the desired concentration is represented in Figure 3.

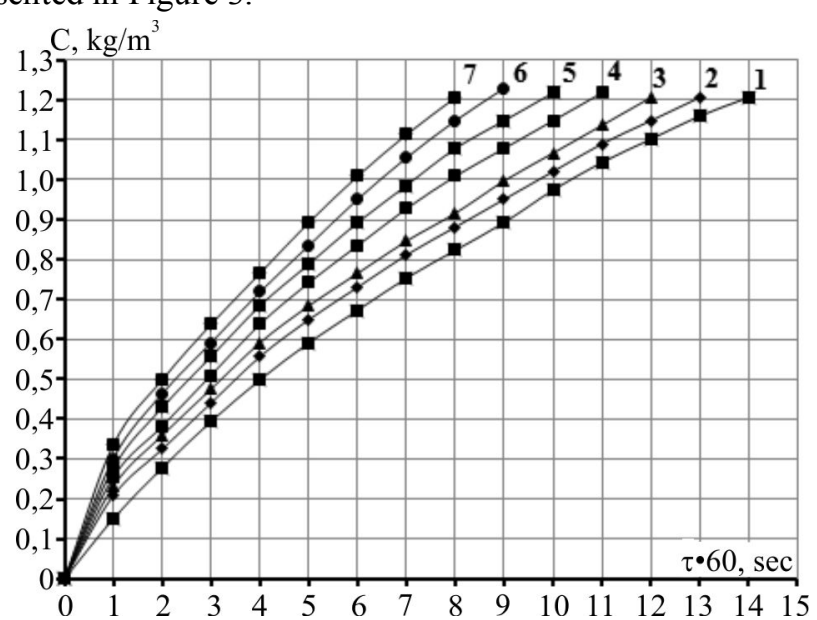

Figure 3. Kinetics of benzoic acid dissolution at variable compressed air consumption until reaching of the concentration $1,2 \mathrm{~kg} / \mathrm{m}^{3}$ : 1) $V_{c}=22 \cdot 10^{-5} \mathrm{~m}^{3} / \mathrm{sec}$; 2) $V_{c}=44 \cdot 10^{-5} \mathrm{~m}^{3} / \mathrm{sec}$; 3) $V_{c}=67 \cdot 10^{-5} \mathrm{~m}^{3} / \mathrm{sec}$; 4) $V_{c}=89 \cdot 10^{-5} \mathrm{~m}^{3} / \mathrm{sec}$; 5) $V_{c}=111 \cdot 10^{-5} \mathrm{~m}^{3} / \mathrm{sec}$; 6) $V_{c}=133 \cdot 10^{-5} \mathrm{~m}^{3} / \mathrm{sec}$; 7) $V_{c}=156 \cdot 10^{-5} \mathrm{~m}^{3} / \mathrm{sec}$

Analyzing the Figure 3, there was discovered that compressed air consumption $5.6 \mathrm{~m}^{3}$ /hour allow performing the benzoic dissolution process to the desired concentration during 8 minutes.

Conclusions. According to experimental investigations, there was discovered that adding of chemically inert mixing additives positively influences the kinetics of dissolution process, reducing its duration and, correspondingly, energy consumption. It was selected the physical and geometric characteristics of mixing additives, and their necessary and sufficient quantity for the process. Additionally, it was determined that adding of mixing spheres prevents displacement of solid substance phase outside of the intensive mass exchange zone into the foam layer. In such manner there 
ensures constant interaction between water and particles and increases the mass exchange surface. In addition, it was estimated the kinetics of benzoic acid dissolution in water during various compressed air consumptions, and determined the critical allowable consumption for conservation of intensive mass exchange between solid and liquid phases. It was also investigated that adding of mixing spheres under compressed air consumption equal to $5.6 \mathrm{~m}^{3} /$ hour reduces the average duration of dissolution process to required concentration down to 130 minutes. It was experimentally investigated and analyzed the kinetics of benzoic acid dissolution in conditions of incomplete saturation to the concentration $C=1.2 \mathrm{~kg} / \mathrm{m}^{3}$ with using of mixing additives.

\section{Перелік використаних джерел}

Danyliuk, O. M., Atamaniuk, V. M., Humnytskyi, Ya., M., \& Bachyk, M. D. (2017). Doslidzhennia zakonomirnostei protsesu periodychnoho rozchynennia polidyspersnykh chastynok benzoinoi kysloty pid chas pnevmatychnoho peremishuvannia. Intehrovani tekhnolohii ta enerhozberezhennia, 4, 36-40. [In Ukrainian].

Danyliuk, O. M., \& Atamaniuk, V. M. (2017). Protses rozchynennia tverdykh polidyspersnykh materialiv pry pnevmatychnomu peremishuvanni na prykladi rozchynennia Benzoinoi kysloty. Zbirnyk materialiv Seminar "Stalyi rozvytok - pohliad u maibutnie". Lviv: Natsionalnyi universytet "Lvivska politekhnika". 20 p. [In Ukrainian].

Garrett, P. R. (2014). The Science of Defoaming: Theory, Experiment and Applications. CRC Press Taylor \& Francis Group - Boca Raton - London - New York.

Kotelnykova, M. N., \& Alikov, N. M. (2011). Penoobrazovanye v penohashenye. Sovremennoe sostoianye problemy. Lambert Academic Publishing's foundation. [In Russian].

Exerowa, D., \& Kruglyakov, P. M. (1998). Foam and Foam Films. Theory, Experiment, Application. Elsevier. 773 p.

Kraievskyi, O. O., \& Mykhailova, T. V. (2009). Problema pinoutvorennia u vyrobnytstvi azotnykh dobryv z domishkamy. Materialy naukovo-tekhnichnoi konferentsii vykladachiv, spivrobitnykiv, aspirantiv $i$ studentiv fakultetu tekhnichnykh system ta enerhoefektyvnykh tekhnolohii. SumDU, Part. 1. 119 p. [In Ukrainian].
Anisimova, O. M. (2014). Pidvyshchennia efektyvnosti tekhnolohichnykh protsesiv za rakhunok ratsionalnoho vykorystannia khimichnykh reahentiv vitchyznianoho vyrobnytstva TOV NVP "Elektrohazokhim". Visnyk tsukrovykiv Ukrainy, 3(94). 20-22. [In Ukrainian].

Shtanheieva, N. I., Klymenko, L. S., Salavor, O. M., \& Sorokin, A. I. (2000) Doslidzhennia pinoutvorennia u vodi oborotnoi systemy hidrotransportu ta myttia buriakiv. Naukovi pratsi UDUKhT, 7. 5962. [In Ukrainian].

Yureva, S. Yu. (2003). Issledovanye y razrabotka sposobov borby s nezhelatelnym penoobrazovanyem $\mathrm{v}$ molochnoi promyshlennosty. Candidate Dissertation for Technical Sciences (05.18.04 - Technology of meat, dairy and fish products and refrigeration industries). Kemerovo, RHB OD, 61:04-5/1658. 134. [In Russian].

James, W. (2007). Sound Methods of Breaking Foam. Fourth Year Project Report. Engineering Science. Finals Part II. 65.

Fazilet, Vardar-Sukan (1998). Foaming: Consequences, prevention and destruction. Biotechnology Advances, 16(5-6), 913-948. https://doi.org/10.1016/S0734-9750(98)00010-X

Karakashev, S. I., , S., \& Grozdanova, M. V. (2012). Foams and antifoams. Advances in Colloid and Interface Science, 176-177, 1-17. https://doi.org/10.1016/j.cis.2012.04.001

Fink, J. (2015). Petroleum Engineer's Guide to Oil Field Chemicals and Fluids (Second Edition). pp. 775-785.

Garrett, P. R. (2015). Defoaming: Antifoams and mechanical methods. Current Opinion in Colloid \& Interface Science, 20(2), 8191. https://doi.org/10.1016/j.cocis.2015.03.007

Liu, Yajun, Wu, Zhaoliang, Zhao, Bin, Li, Lingling, \& Li, Rui (2013). Enhancing defoaming using the foam breaker with perforated plates for promoting the application of foam fractionation. Separation and $\begin{array}{lll}\text { Purification } & \text { Technology, } & 120,19 .\end{array}$ https://doi.org/10.1016/j.seppur.2013.09.021

Shapoval, Y. M., Poliuzhyn, I. P., Tsiupko, F. I., \& Poliuzhyn, L. I. (2017). Otsinka efektyvnosti pinohasnykiv dlia vodnykh rozchyniv poliakrylamidu ta lauretsulfatu natriiu yak osnovy mastylno-okholoduvalnykh tekhnolohichnykh ridyn. Visnyk Natsionalnoho universytetu "Lvivska politekhnika". Seriia: Khimiia, tekhnolohiia rechovyn ta yikh zastosuvannia, 868. 419-427. [In Ukrainian].

О. М. Данилюк, В. М. Атаманюк, З. Я. Гнатів

Національний університет "Львівська політехніка", м. Львів, Україна

\section{ВПЛИВ ПЕРЕМІШУВАЛЬНИХ ТВЕРДИХ ЧАСТИНОК НА КІНЕТИКУ РОЗЧИНЕННЯ БЕНЗОЙНОЇ КИСЛОТИ ПІД ЧАС ПНЕВМАТИЧНОГО ПЕРЕМШШУВАННЯ РОЗЧИНУ}

Охарактеризовано закономірності процесу розчинення полідисперсної суміші бензойної кислоти під час пневматичного перемішування розчину. Зосереджено увагу на використанні твердих хімічно інертних перемішувальних додатків, які вводяться до розчину на початку процесу, що покращує ефективність перемішування, одночасно зменшуючи кількість утвореної піни. Оцінено вплив цих твердих частинок різних форм, виготовлених з хімічно інертних до бензойної кислоти матеріалів (скло, пластик, гума, поліацеталь), на процес пневматичного перемішування і, відповідно, на кінетику розчинення бензойної кислоти у воді. З'ясовано, що оптимальними для перемішування розчину бензойної кислоти $є$ частинки кулястої форми, виготовлені із пластику, із такими характеристиками: діаметром 7 мм, питомою густиною 1280 кг/м³. Експериментальні дослідження дали змогу встановити, що введення перемішувальних додатків у частці $2 \%$ від об'єму розчину є граничним $\mathrm{i}$ достатнім, щоб запобігти винесенню твердої фази у шар піни і цим самим зменшити тривалість процесу розчинення до заданої концентрації. Досліджено вплив перемішувальних додатків на тривалість розчинення та на витрати енергоносіїв. Встановлено гранично допустиму витрату стиснутого повітря, яка запобігає переходу розчину у стан піни. Також досліджено вплив змінної витрати повітря на кінетику процесу розчинення. Експериментально досліджено і проаналізовано кінетику розчинення бензойної кислоти за умов неповного насичення розчину до концентрації 1,2 кг/м³ у присутності перемішувальних додатків.

Ключові слова: розчинення; перемішування; барботер; піноутворення; масообмін; кінетика.

О. М. Данилюк, В. М. Атаманюк, З. Я. Гнатив

Национальный университет "Львовская политехника", г. Львов, Украина

\section{ВЛИЯНИЕ ПЕРЕМЕШИВАЮЩИХ ТВЕРДЫХ ЧАСТИЦ НА КИНЕТИКУ РАСТВОРЕНИЯ БЕНЗОЙНОЙ КИСЛОТЫ ВО ВРЕМЯ ПНЕВМАТИЧЕСКОГО ПЕРЕМЕШИВАНИЯ РАСТВОРА}

Охарактеризованы закономерности процесса растворения полидисперсной смеси бензойной кислоты во время пневматического перемешивания раствора. Внимание сосредоточено на использовании твердых химически инертных перемешивающих приложений, которые вводятся в раствор в начале процесса, улучшает эффективность перемешивания, одновременно 
уменьшая количество образованной пены. Оценено влияние этих твердых частиц различных форм, изготовленных из химически инертных к бензойной кислоте материалов (стекло, пластик, резина, полиацеталь), на процесс пневматического перемешивания и, соответственно, на кинетику растворения бензойной кислоты в воде. Установлено, что оптимальными для перемешивания раствора бензойной кислоты являются частицы шарообразной формы, изготовленные из пластика, с такими характеристиками: диаметром 7 мм, удельным весом 1280 кг/м³. Экспериментальные исследования позволили установить, что введение перемешивающих приложений в количестве $2 \%$ от объема раствора является предельным и достаточным, чтобы предотвратить вынос твердой фазы в слой пены и тем самым уменьшить продолжительность процесса растворения до заданной концентрации. Исследовано влияние перемешивающих приложений на продолжительность растворения и на расходы энергоносителей. Установлен предельно допустимый расход сжатого воздуха, который предотвращает переход раствора в состояние пены. Также исследовано влияние переменной расхода воздуха на кинетику процесса растворения. Экспериментально исследована и проанализирована кинетика растворения бензойной кислоты в условиях неполного насыщения раствора до концентрации 1,2 кг/м ${ }^{3}$ в присутствии перемешивающих приложений.

Ключевые слова: растворение; перемешивание; барботер; пенообразование; массообмен; кинетика. 